\title{
Adaptability of Growth and Yield on 5 Varieties of Shallot (Allium ascalonicum L.) in Wet Highland
}

\author{
Agustina E Marpaung ${ }^{1 *}$ and Rini Rosliani ${ }^{2}$ \\ ${ }^{1}$ Berastagi Experimental Farm (Indonesian Vegetables Research Institute) Jl. Raya Medan-Berastagi Km. 60 Berastagi, 22156 \\ ${ }^{2}$ Indonesian Vegetables Research Institute Jl. Tangkuban Perahu 517 Lembang 40391 Bandung, Indonesia \\ *Corresponding author: agustinamarpaung@pertanian.go.id
}

\section{ARTICLE HISTORY}

$\begin{array}{ll}\text { Received } & : \text { 19 February } 2019 \\ \text { Revised } & : 12 \text { March } 2019 \\ \text { Accepted } & : 26 \text { April } 2019\end{array}$

\section{KEYWORDS}

Allium cepa var. ascalonicum, Adaptation

Growth

Yield

Varieties

\begin{abstract}
In general, shallot was planted in low land to highland, but it usually planted in area has rain fall and humidity not high, because can effect to the yielding, so that needed the adaptive varieties in the condition. The aim of the research was to determine the growth and yield of some varieties of shallot adaptive in wet highlands. The research conducted in Berastagi experimental farm, Dolat Rayat district, Karo regency, with type of the soil is andisol and altitude of $1,340 \mathrm{~m}$ asl. The research was beginning from September - December 2015. The design was used randomize block non factorial with 5 replication. The treatment was shallot varieties (Bima, Maja, Trisula, Agrihorti 1 and Agrihorti 2). The shallot seeds were from Java. The result showed that the Agrihorti 1 and Bima varieties had a more adaptive vegetative growth in wet highland than 3 other varieties. Agrihorti 1 and Bima varieties produced the highest bulb production respectivaly i.e. $12,76 \mathrm{~kg} / 5 \mathrm{~m}^{2}$ and 12,61 kg/5 $\mathrm{m}^{2}$. Agrihorti 1 varieties have the largest bulb diameter 2,99 $\mathrm{cm}$. Shallot Agrihorti 1 varieties adaptive in the wet highland.
\end{abstract}

This is an open access article under the CC-BY-SA license.

\section{INTRODUCTION}

Shallot (Allium ascalonicum L.) is one of the vegetable commodities that have significance for the community, both seen from the economic value and the nutritional content. Although it is realized that shallot is not a necessity, but its needs can hardly be avoided by household consumers (Nur and Thohari, 2005).

Shallot is a plant that has extensive adaptation. Some varieties originating from the highlands and the middle are able to adapt well in the lowlands (Kusmana et al., 2009). Shallot is also able to grow in Alluvial soil (Firmansyah et al., 2015; Sumarni et al., 2012), coastal sand soil (Swasono, 2012), on peat land (Satsijati and Koswara, 1993; Firmansyah et al., 2014).

Indonesia with 34 provinces, 325 districts, 5,054 districts have potential areas of shallot production. These areas include: Aceh, North Sumatra, West Sumatra, Jambi, Lampung, West Java, Central Java, DI Yogyakarta, East Java, West Nusa Tenggara, Bali, Central Sulawesi, South Sulawesi, North Sulawesi and Papua (Direktorat Jenderal Pengolahan dan Pemasaran Hasil Pertanian, 2006).

The areas of Cirebon, Brebes, Tegal, Kuningan, Wates (Yogyakarta), East Lombok and Samosir are the production centers of shallots in Indonesia (Sunarjono and Soedomo, 1989 in (Sumarni, 2005). In 2003, the total cultivation of shallots of Indonesian farmers was 88,029 hectares with an average yield of $8.7 \mathrm{t} / \mathrm{ha}$. In North Sumatera, shallot production in 2012 increased by 1,707 tons $(13.71 \%)$ compared to 2011 . The increase in production was due to the increase of harvested area (BPS North Sumatra, 2013). However, the productivity of shallot yield is considered low, because the potential yield can be reached about $20 \mathrm{t} / \mathrm{ha}$. For the success of shallot cultivation in addition to using superior varieties, needs to be meeting the requirements of the growth of the principal and good cultivation techniques.

The shallot production center in North Sumatera is Simalungun Regency which ranks first, followed by Toba Samosir, Karo, Dairi, Samosir and North Tapanuli. Data obtained from the Agriculture Office of North Sumatra mention that the area of shallot cultivation in North Sumatra in 2010 reached 1,379 hectares and in 2011 increased to 1,408 hectares. Meanwhile, the realization of the harvest in 2010 was 1,360 hectares and in 2011 1,296 hectares. Yields in 2010 amounted to 9,413 tons and in 2011 increased to 12,175 tons (Sekretariat Kabinet Republik Indonesia, 2012).

The shallot plants prefer to grow in dry climates. The shallot plants are sensitive to rainfall and high rainfall intensity, as well as foggy weather. This plant requires maximum sunlight exposure (at least $70 \%$ irradiation), 
air temperature $25-32{ }^{\circ} \mathrm{C}$, and $50-70 \%$ relative humidity (Subhan, 1990; Nazarudin, 1999 in Sumarni, 2005).

Shallot plants can form bulbs in areas with an average air temperature of $22{ }^{\circ} \mathrm{C}$, but the bulb yields are not as good as in areas with warmer temperatures. Shallot plants will form larger bulbs when planted in areas with irradiation more than 12 hours. Under air temperature $22^{\circ} \mathrm{C}$ shallot plants will not be bulbous. Therefore, shallot plants prefer to grow in the lowlands with a sunny climate (Rismunandar, 1986 in Sumarni, 2005).

In Indonesia, shallot can be planted in the lowlands to a height of $1000 \mathrm{~m}$ above sea level. The optimal place height for shallot growth and development is $0-450 \mathrm{~m}$ above sea level (Sutarya \& Grubben, 1995 in Sumarni, 2005). Shallot plants can still grow and bulb in the highlands, but the age of planting becomes longer 0.5-1 months and bulb yield is lower. For that done some efforts in the planting in the highland so that it can produce the production and quality of shallot bulbs are good.

Research by Limbongan and Maskar (2003) has produced a technology package including planting, fertilizing, irrigation, pest control, yield processing, and marketing systems. The application of cultivation technology turned out to be able to increase the yield of dried onions up to $4.91 \mathrm{t} / \mathrm{ha}$, it could even reach $10 \mathrm{t} / \mathrm{ha}$ by using good seeds and the right spacing.

Shallot cultivation is still constrained by the availability of seeds (Kusmana et al., 2009). To get the needs of seeds, farmers often use imported shallot seeds from imports (Basuki, 2005). This was caused not only by the limited availability of local seeds, but also because local varieties had a relatively small bulbr size compared to Ilokos imported varieties and bulb yields were lower than imported Tanduyung varieties (Kusmana et al., 2007).

This research aims to determine the growth and yield of some varieties of shallot adaptive in the wet highland.

\section{MATERIALS AND METHODS}

The research was conducted at Berastagi experimental farm, Dolat Rayat District, Karo District, with andisol soil type, altitude of $1,340 \mathrm{~m}$ asl, temperature of $220-280 \mathrm{C}$, humidity $80-90 \%$ and rainfall $2,500 \mathrm{~mm} /$ year, and starting in September until December 2015.

The research used non factorial Randomized Block Design (RBD) with 5 replications. The treatments consisted of five varieties i.e. Bima, Maja, Trisula, Agrihorti 1, and Agrihorti 2.

Shallot seeds in the form of bulb from Java. The procedure was made bed with size $1 \times 5 \mathrm{~m}$, distance between treatment $70 \mathrm{~cm}$ and distance between replication $1 \mathrm{~m}$. The basic fertilizer used is organic fertilizer $2 \mathrm{~kg} / \mathrm{m}^{2}$ plus TSP $15 \mathrm{~g} / \mathrm{m}^{2}$. Planting using black plastic mulch with plant spacing $20 \times 20 \mathrm{~cm}$. Subsequent fertilization is given $1 \times 2$ weeks by watering using NPK 16-16-16 (20 g/l water). Maintenance includes weeding, watering and controlling pests and diseases. To prevent plant pest attack, spraying insecticide with active ingredient of Sipermetrin $50 \mathrm{~g} / \mathrm{l}$, Pyridaben $135 \mathrm{~g} / \mathrm{l}$ and Spinetoram $120 \mathrm{~g} / \mathrm{l}$, with concentration $0,5-1,0 \mathrm{cc} / \mathrm{l}$ of water, to control the plant diseases is fungicide spraying chlorotalomile $2 \mathrm{~g} / \mathrm{l}$ water and azoksistrobin $200 \mathrm{~g} / \mathrm{l}+$ diphenocanazole $125 \mathrm{~g} / \mathrm{l} 0.5-1 \mathrm{ml} / \mathrm{l}$ water. Spraying is done 1 time for 4 days or depending on the level of pests and diseases in the field. Harvesting done 3 months after planting.

The observed variables were as follows: plant height and clumps diameter at 1 and 2 months, number of tillers, number of bulbs, bulb diameter, bulb weight per plant and production per plot. The data from observed variables were tested by Analysis of Variance (ANOVA test) and continued with mean difference test according to $\mathrm{BNJ}$ at $5 \%$ level.

\section{RESULTS AND DISCUSSIONS}

\subsection{Plant Height}

The result of statistical analyses on plant height at 1 and 2 months after planting (MAP) showed that the treatment of varieties had significant effect (Table 1).

The varieties of Agrihorti 1 differed significantly from other varieties $(40.83 \mathrm{~cm})$ at $1 \mathrm{MAP}$. So as at $2 \mathrm{MAP}$, Agrihorti 1 varieties showed the highest growth (50.93 $\mathrm{cm}$ ), but it not significantly different with Bima varieties $(49.19 \mathrm{~cm})$. This suggests that Agrihorti 1 and Bima varieties have more adaptive growth in the wet highland of Berastagi.

Table 1. Plant height and percentage of growth increase of 5 shallot varieties at 1 and 2 month after plant

\begin{tabular}{lccc}
\hline \multirow{2}{*}{ Varieties } & \multicolumn{2}{c}{ Plant Height (cm) } & \begin{tabular}{c} 
Percentage of \\
Growth Increase \\
\cline { 2 - 4 } (\%)
\end{tabular} \\
\cline { 2 - 4 } Bima & 1 MAP & 2 MAP & $80,53 \mathrm{a}$ \\
Maja & $31,47 \mathrm{~b}$ & $38,29 \mathrm{c}$ & $21,37 \mathrm{c}$ \\
Trisula & $27,95 \mathrm{c}$ & $38,19 \mathrm{c}$ & $36,35 \mathrm{~b}$ \\
Agrihorti 1 & $40,83 \mathrm{a}$ & $50,93 \mathrm{a}$ & $25,26 \mathrm{bc}$ \\
Agrihorti 2 & $33,43 \mathrm{~b}$ & $44,68 \mathrm{~b}$ & $33,61 \mathrm{bc}$ \\
\hline \multicolumn{1}{c}{ CV (\%) } & $\mathbf{5 , 4 4}$ & $\mathbf{5 , 9 9}$ & $\mathbf{1 8 , 0 9}$ \\
\hline
\end{tabular}

Note : Means followed by the same letters on the same column is not significantly different according to honestly significantly different test at $5 \%$ level. $\mathrm{MAP}=$ months after planting.

The varieties of Bima significantly resulted in a higher percentage increase in growth compared to other varieties, which is $80.53 \%$. This could be seen from the growth chart of plant height from age 1 MAP to age 2 MAP (Fig 1).

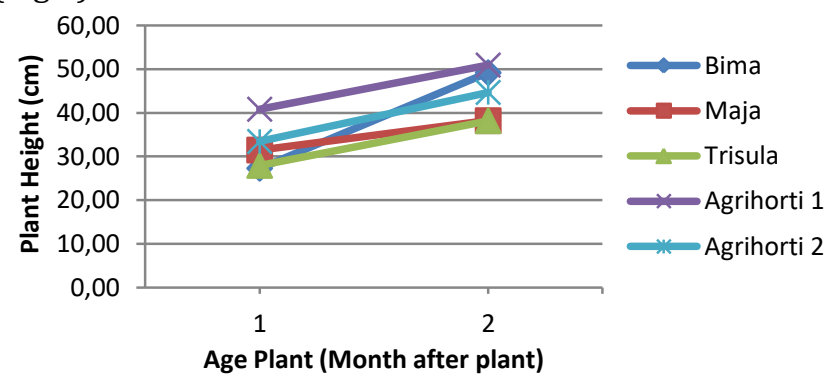

Figure 1. Plant height at 1 and 2 months after plant 


\subsection{Diameter of Plant Clumps at 1 and 2 Month after Plant}

Based on result of analysis of variance indicate that diameter of clump of plant at 1 and 2 month after plant (MAP) have significant effect to shallot varieties treatment (Table 2).

Table 2. Diameter of plant clumps on 5 shallot varieties at 1 and 2 months after plant

\begin{tabular}{lccc}
\hline \multirow{2}{*}{ Varieties } & \multicolumn{3}{c}{ Diameter of Plant Clumps (cm) } \\
\cline { 2 - 4 } & 1,20 & c & 2 MAP \\
\hline Bima & 0,91 & c & $5,74 \mathrm{a}$ \\
Maja & 2,64 & a & $2,44 \mathrm{~b}$ \\
Trisula & 2,29 & ab & $2,96 \mathrm{~b}$ \\
Agrihorti 1 & 2,08 & b & 2,64 b \\
Agrihorti 2 & $\mathbf{1 1 , 8 2}$ & $2,26 \mathrm{~b}$ \\
\hline \multicolumn{1}{c}{ CV (\%) } & & $\mathbf{1 1 , 2 8}$
\end{tabular}

Note : Means followed by the same letter on the same column is not significantly different according to honestly significantly different test at $5 \%$ level

Table 2 above shows that the diameter of Trisula varieties at 1 MAP is significantly higher than other varieties, which is $2.64 \mathrm{~cm}$, and not significantly different from Agrihorti 1 varieties $(2.29 \mathrm{~cm})$. At $2 \mathrm{MAP}$, diameter of clump of Bima varieties was significantly higher than other varieties, which is $5.74 \mathrm{~cm}$, while among other varieties there was no significant difference. It was alleged that the vegetative growth of Bima varieties potentially more adaptive growth in the wet highland.

An increase in the diameter of each variety at 1 and 2 months after planting can be seen in Figure.2, where the growth of the clumps of Bima varieties is very significant increase from 1 until 2 MAP.

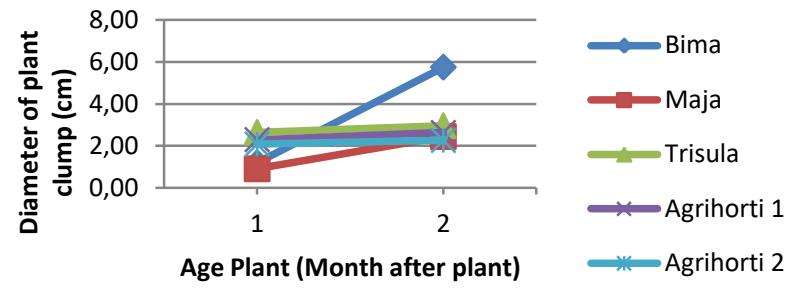

Figure 2. Diameter of plant clump at 1 and 2 months after plant

The growth of the 5 varieties of shallot plant can be seen in Figure 3.

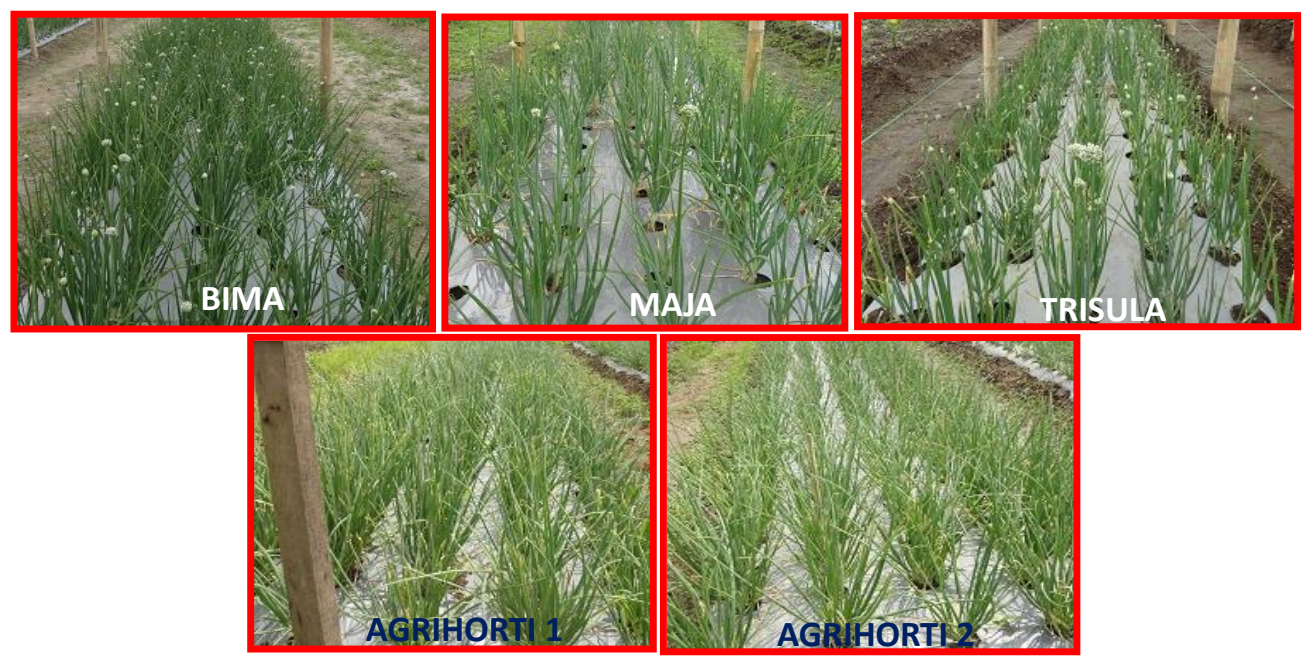

Figure 3. The growth of 5 shallot varieties

\subsection{Weight per Plant and Production per Plot}

The result of statistical analysis showed that shallot varieties had significant effect on the tillers number, bulb number, and bulb diameter, bulb weight per plant and production per plot (Table 3 ).

Table 3. Number of tillers, bulb number, bulb diameter, bulb weight per plant and production per plot on 5 shallot varieties

\begin{tabular}{lccccc}
\hline Varieties & Number of Tillers & Bulb Number & $\begin{array}{c}\text { Bulb Diameter } \\
\text { (cm) }\end{array}$ & $\begin{array}{c}\text { Bulb Weight } \\
\text { (g/plant) }\end{array}$ & $\begin{array}{c}\text { Production } \\
\left(\mathbf{k g} / \mathbf{5} \mathbf{~ m}^{2}\right)\end{array}$ \\
\hline Bima & $7,57 \mathrm{a}$ & $13,58 \mathrm{a}$ & $2,22 \mathrm{c}$ & $103,97 \mathrm{a}$ & $12,61 \mathrm{a}$ \\
Maja & $3,60 \mathrm{c}$ & $4,28 \mathrm{~d}$ & $2,70 \mathrm{ab}$ & $47,38 \mathrm{c}$ & $5,71 \mathrm{c}$ \\
Trisula & $5,48 \mathrm{~b}$ & $6,49 \mathrm{c}$ & $1,78 \mathrm{~d}$ & $48,35 \mathrm{c}$ & $5,87 \mathrm{c}$ \\
Agrihorti 1 & $6,63 \mathrm{ab}$ & $9,07 \mathrm{~b}$ & $2,99 \mathrm{a}$ & $105,07 \mathrm{a}$ & $12,76 \mathrm{a}$ \\
Agrihorti 2 & $7,73 \mathrm{a}$ & $7,50 \mathrm{bc}$ & $2,38 \mathrm{bc}$ & $84,32 \mathrm{~b}$ & $10,23 \mathrm{~b}$ \\
\hline \multicolumn{1}{c}{ CV (\%) } & $\mathbf{1 5 , 2 5}$ & $\mathbf{1 3 , 1 2}$ & $\mathbf{7 , 0 6}$ & $\mathbf{9 , 7 9}$ & $\mathbf{1 0 , 5 4}$ \\
\hline
\end{tabular}

Note : Means followed by the same letter on the same column is not significantly different according to honestly significantly different test at $5 \%$ level. 
The number of tillers of each shallot varieties was found to be a significant difference. The varieties of Agrihorti 2 (7,73 tillers) and Bima (7,57 tillers) were significantly higher than the other varieties, but it was not significantly different from Agrihorti 1 varieties (6.63 tiller). The lowest number of tillers was found in the Maja varieties, which is 3.60 tillers.

The varieties of Bima also produced the highest number of bulbs among other varieties, which is 13.58 bulbs. While the lowest one is Maja varieties, which is 4.28. This showed that the varieties of Bima had suitable ecosystem to forming the bulb. The number of shallot bulbs or the number of tillers that differ between varieties shows the influence of genetic factors (Firmansyah, 2018). Budianto et al. (2009), said that the character of shallot bulbs is influenced by genetic factors and few by environmental factors.

Agrihorti 1 varieties significantly yielded bulb diameter larger than other varieties, which is $2.99 \mathrm{~cm}$, but it was not significantly different with Maja varieties $(2.70 \mathrm{~cm})$. The lowest bulb diameter was found on Trisula varieties, which is $1.78 \mathrm{~cm}$. This indicates that the Agrihorti 1 and Maja varieties had larger bulb size and Trisula varieties the smallest bulb size.

The highest bulb weight per plant and production per plot of shallot were found in Agrihorti 1 and Bima varieties, which is $105,07 \mathrm{~g}$ and $103,97 \mathrm{~g}$ per plant, as well as $12,76 \mathrm{~kg}$ and $12,61 \mathrm{~kg}$ per plot, respectively. Differences in production in each variety other than influenced by external factors are also influenced by genetic factors (Putrasamedja et al., 2006). The size of each bulb will affect the production capability of each clone / varieties (Sumarni \& Sutiarso, 1998).

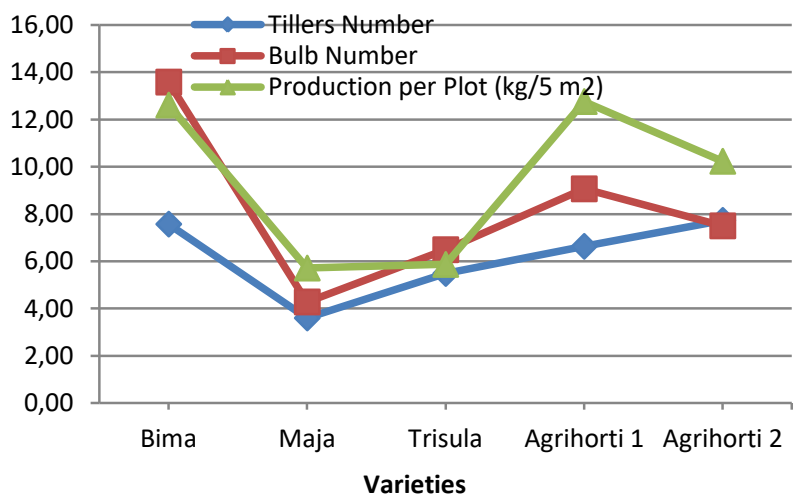

Figure 4. Relationship between number of tillers, bulb number and production

In Figure 4 it can be seen that the relationship between the number of tillers, the number of bulb and the production per plot on the 5 varieties of shallot tested in general is directly proportional. Where for each variety that produces a higher number of tillers will result in a higher number of and production as well. Similarly, if the number of tillers is lower, it will produce the number of bulbs and lower production as well. This is supported by (Putrasamedja 2010), that the more number of tillers tend to be higher the weight per clumps. This was also supported by Firmansyah (2018) who said the productivity of shallots was influenced by the parameters of the number of bulbs as reflected by the number of tillers and the weight of tuber produced.

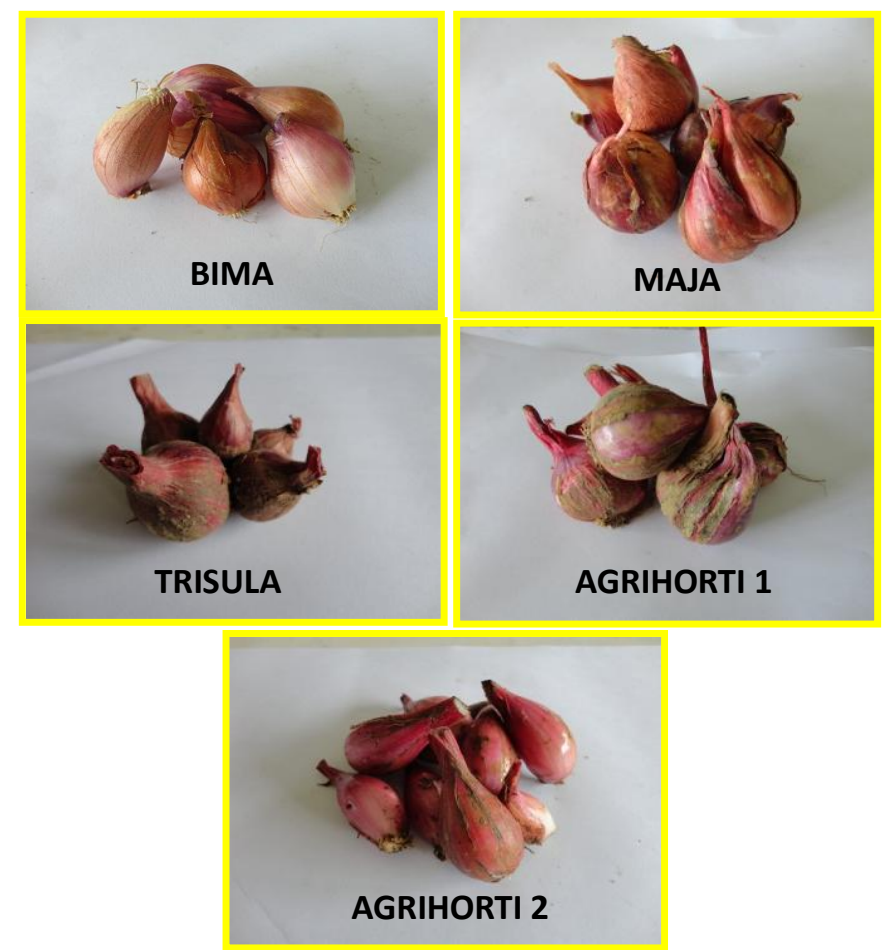

Figure 5. Appearance bulb form of 5 shallot varieties

\section{CONCLUSION}

Agrihorti 1 and Bima of shallot varieties had a more adaptive vegetative growth in the wet highland than 3 other varieties. Agrihorti 1 and Bima varieties produced the highest bulb production i.e.12,76 kg / $5 \mathrm{~m} 2$ and 12,61 $\mathrm{kg} / 5 \mathrm{~m} 2$ respectivaly. Agrihorti 1 varieties have the largest bulb diameter 2,99 $\mathrm{cm}$. Shallot Agrihorti 1 variety adaptive in the wet highland.

\section{REFERENCES}

Badan Pusat Statistik Kabupaten Karo, 2013. Karo in numbers. Kabupaten Karo Sumatera Utara.

Basuki, S.R. 2005. Research on Farmer's Results and Preferences on Local Varities of Red Onion from Various Regions. Research Report APBN 2005- ROPP D1. Pp. 8.

Budianto, Aris, Ngawit and Sudika, 2009. Genetic diversity of several traits and simple recurrent clone selection on Ampenan cultivar shallots. Crop Agro. vol. 2, no. 1, pp. 28-38.

Direktorat Jenderal Pengolahan dan Pemasaran Hasil Pertanian, 2006. Post-Harvest Road Map, Shallot Processing and Marketing. Direktorat Jenderal Pengolahan dan Pemasaran Hasil Pertanian.

Firmansyah, L. Liferdi, N. Khaririyatun, and M.P. Yufdi, 2015. The growth and yield of shallots with the application of organic fertilizers and biological fertilizers on alluvial soil. J. Hort. vol. 25, no. 2, pp. 133-141.

Firmansyah, M.A,, D. Musaddad, T. Liana, M.S. Mokhtar, and M.P. Yufdi, 2014. Adaptation test to shallots during the rainy season in Central Kalimantan. J. Hort. vol. 24, no. 2, pp. 114-123.

Firmansyah, M.A, D. Musaddad, T. Liana, M.S. Mokhtar, and M.P. Yufdi, 2018. Growth, Production and Quality of Shallots in the Land of Inland Quartz off-season. Jurnal Agroekoteknologi FP USU, vol.6, 
no.2, pp. 271 - 278, E-ISSN No. 2337- 6597.

Kusmana, E. Sofiari, and R.S. Basuki, 2007. Shallot (Allium ascalonicum L) Local Cultivar High Yield Selection at Slatri, Brebes. (Unpublished), p.6.

Kusmana, R.S. Basuki, and H. Kurniawan, 2009. Test of adaptation of five shallot varieties from high and medium origin in the Brebes lowland ecosystem. J. Hort. vol. 19, no. 3, pp. 281-286.

Limbongan, J and Maskar, 2003. Potential development and availability of onion technology in Palu, Central Sulawesi. Jurnal Litbang Pertanian, vol. 22, no. 3, pp. 103-108.

Nur, S and Thohari, 2005. Respond to Nitrogen Doses and Application of Various Types of Bolus to the Growth and Yield of Shallot Plants (Allium ascalonicum L.). Dinas Pertanian, Kabupaten Brebes.

Putrasamedja, S., J. Pinilih, and S. Basuki, 2006. Paper for the Release of Shallot Superior Varieties, Indonesian Vegetables Reseach Institute.

Putrasamedja, S., 2010. Adaptation of Shallot Clones in the Rainy Season. Agronomika, vol. 10, no. 1, pp. 69-76. ISSN: 1411-8297.

Satsijati and E. Koswara, 1993. The study of the application of technology formulations for cultivation of chilli and shallots on tidal land. J. Hort. vol. 3, no. 1, pp. 13-20.

Sekretariat Kabinet Republik Indonesia, 2012. Pressing the Suppressing Imports, North Sumatra Expands Shallot Land. Sekretariat Kabinet Republik Indonesia, www.setkab.go.id, accessed on October 14, 2012.

Subhan, 1990. Effect of NPK doses (15-15-15) on growth and yield of shallots (Allium ascalonicum L) Bima cultivars. Bul. Penel. Hort. vol. XIX, no. 3, hlm. 109-118.

Sumarni, N and T.A. Soetiarso, 1998. Effect and size of seed bulbs on growth, production and cost of producing shallot seeds. Jurnal Hortikultura, vol. 8, no. 2, hlm.1085.

Sumarni, N and A. Hidayat, 2005. Shallot cultivation, technical guide for shallots cultivation. vol. 3, ISBN : 979-8304-49-7, pp. 1-3.

Sumarni N, R. Rosliani, and R.S. Basuki, 2012. Growth response, bulb yield, and nutrient uptake of NPK of onion plants to various dosages of NPK fertilization on Alluvial soils. J. Hort. vol. 22, no. 4, pp. 365-374.

Swasono, F.D.H., 2012. The physiological characteristics of the tolerance of shallots to drought stress in coastal sand soil. Jurnal AgriSains, vol. 3, no. 4, pp. 88-103. 